\title{
Keanekaragaman dan Pola Sebaran Moluska (Gastropoda dan Bivalvia) yang Berasosiasi Pada Ekosistem Mangrove di Pesisir Selatan Lombok Timur
}

\section{Diversity and Distribution Patterns of Molluscs (Gastropods and Bivalves) Associated with Mangrove Ecosystems on the South Coast of East Lombok}

\author{
Wayan Pasek Eka Sedana Putra*, Didik Santoso, Abdul Syukur \\ Pendidikan Biologi, Fakultas Keguruan dan Ilmu Pendidikan, Universitas Mataram, \\ Mataram, Indonesia \\ *Corresponding Author Email : wayanpasekeka@gmail.com
}

Manuscript received: 08-09-2021. Accepted: 27-10-2021

\begin{abstract}
ABSTRAK
Ekosistem mangrove memiliki peran penting di daerah pesisir. Mangrove memiliki fungsi sebagai tempat berlindung, mencari makan, dan berkembang biak berbagai biota akuatik. Kerusakan hutan mangrove dapat menyebabkan pelayaan ekosistem mangrove akan semakin berkurang, khususnya bagi kehidupan moluska. Moluska adalah salah satu biota asosiasi mangrove yang kehidupannya dipengaruhi oleh keberadaan hutan mangrove. Oleh karena itu, tujuan penelitian ini adalah untuk mengetahui keanekragaman moluska serta hubungan kepadatan moluska dengan kepadatan mangrove yang terdapat pada ekosistem mangrove pesisir selatan Lombok Timur. Pengambilan sampel moluska menggunakan metode quadrate sampling secara purposive sampling dengan memperhatikan spesies mangrove yang terdapat dalam plot pengamatan. Data yang telah dikoleksi dianalisis dengan indeks keanekaragaman, pola sebaran, asosiasi, dan koefisien korelasi pearson. Selanjutnya dilakukan analisis regresi linier sederhana dengan variable independen $(\mathrm{x})$ kepadatan mangrove dan variable dependen (y) kepadatan moluska. Hasil penelitian ini adalah ditemukannya 22 spesies moluska yang terdiri dari 17 spesies gastropoda dan 5 spesies bivalvia. Kepadatan moluska di ekosistem mangrove pesisir selatan Lombok Timur adalah 44.50 \pm 2.63 ind./m2. Indeks keanekaragaman di lokasi penelitian tergolong sedang dengan nilai berkisar $1.99-2.46$. Pola sebaran moluska di lokasi penelitian adalah mengelompok dengan nilai Id $>1$. Terdapat 8 spesies moluska yang berasosiasi dengan 3 spesies mangrove dari 22 spesies moluska yang ditemukan. Persamaan regresi linier $\mathrm{y}=0.084 \mathrm{x}-0.2963$ dengan nilai koefisien korelasi pearson (r) 0,95 menggambarkan hubungan yang kuat antara variabel independen (x) kepadatan mangrove dengan variabel dependen (y) kepadatan molusk. Kesimpulan dari penelitian ini adalah adanya hubungan yang signifikan antara kepadatan mangrove dan kepadatan moluska yang ditunjukan dengan nilai fhitung (41.01) > ftabel (7.70) dan $\mathrm{P}$ value $(0.003)<\alpha(0.05)$.
\end{abstract}

Kata kunci : kepadatan moluska; keanekaragaman; asosiasi; polas sebaran 


\begin{abstract}
Mangrove ecosystems have an important role in coastal areas. Mangroves have a function as a shelter, foraging for food, and breeding various aquatic biota. Damage to mangrove forests can cause the service of mangrove ecosystems to decrease, especially for mollusk life. Mollusks are one of the associated biotas of mangroves whose life is influenced by mangrove forests. Therefore, the purpose of this study was to determine the diversity of mollusks and the relationship between mollusk density and mangrove density in the mangrove ecosystem of the southern coast of East Lombok. A sampling of mollusks used the quadrate sampling method by purposive sampling by taking into account the mangrove species contained in the observation plot. The collected data were analyzed by diversity index, distribution pattern, association, and Pearson correlation coefficient. Then a simple linear regression analysis was performed with the independent variable (x) mangrove density and the dependent variable (y) mollusk density. The results of this study were the discovery of 22 species of mollusks consisting of 17 species of gastropods and five species of bivalves. The density of mollusks in the mangrove ecosystem of the southern coast of East Lombok is $44.50 \pm 2.63$ ind./m2. The diversity index at the study site was classified as moderate, with a value ranging from 1.99 to 2.46 . The distribution pattern of mollusks at the research site is clustered with an Id value $>1$. There are eight mollusk species associated with three mangrove species from 22 mollusk species found. The linear regression equation $\mathrm{y}=0.084 \mathrm{x}-0.2963$ with a Pearson correlation coefficient $(\mathrm{r}) 0.95$ describes a strong relationship between the independent variable (x) mangrove density and the dependent variable (y) mollusk density. This study concludes that there is a significant relationship between mangrove density and mollusk density as indicated by F-hit(41.01) > F-table (7.70) and Pvalue $(0.003)<(0.05)$.
\end{abstract}

Keywords : mollusk density; diversity; association; distribution pattern

\title{
PENDAHULUAN
}

Moluska termasuk dalam salah satu filum invertebrata yang secara umum bertubuh lunak dan sebagian besar dilindungi oleh cangkang (Gosling, 2002). Filum ini terdiri dari 110.000 spesies yang terbagi kedalam 9 kelas, yaitu Amphineura, Gastropoda, Scaphopoda, Bivalvia, Cephalopoda, Caudovofeata, Solenogastres, Monoplacophora, dan Polyplachopora (Hyman, 1967; Parker, 1982). Dua kelas dari filum moluska yang memiliki jumlah spesies terbesar adalah kelas gastropoda dan kelas bivalvia (Dharma, 1988).

Moluska dapat ditemukan pada kondisi habitat yang beragam mulai dari daerah tropik, danau, daerah berlumpur, dan pada lautan lepas dari permukaan hingga ke dasar laut (Hickman, et al., 2008). Moluska juga dapat hidup pada substrat berpasir, berbatu, dan berlumpur (Cappenberg, 2016). Hampir 60\% dari total spesies moluska dapat hidup di perairan dengan kadar salinitas tinggi (Mudjiono, 2009; Reece, et al., 2014). Salah satu habitat moluska yang terdapat di kawasan pesisir adalah hutan mangrove.

Hutan mangrove memberikan kelembaban substrat yang tinggi serta tempat berlindung yang baik sehingga mampu mendukung kehidupan moluska (Suartini et al., 2013). Selain itu, hutan mangrove berfungsi sebagai tempat mencari makan (feeding ground), tempat memijah (spawning ground), dan tempat berkembang biak bagi berbagai biota laut (Negelkerken et al., 2008). Sedangkan komunitas moluska memiliki peranan ekologis bagi hutan mangrove sebagai pengurai serasah dengan cara merobek dan memperkecil serasah, subyek dalam siklus karbon melalui proses respirasi dan kalsifikasi 
serta sebagai bioindikator pencemaran dan bioindikator logam (Putri et al., 2012; Ayu et al., 2015; Karimah, 2017; Isnaningsih et al., 2018).

Luas kawasan hutan mangrove di Pulau Lombok adalah 3.426, 78 ha dengan lokasi kerusakan hutan mangrove tertinggi berlokasi di Kabupaten Lombok Timur dengan luas 1.493, 56 ha (Budhiman et al., 2010). Sebagian besar penyebab kerusakan hutan mangrove tersebut bukanlah pengaruh lingkungan, melainkan aktivitas manusia, yaitu peralihan fungsi lahan oleh masyarakat sekitar menjadi tambak garam, pertanian, perikanan, dan perumahan (Subhan et al., 2014; Raharjo et al., 2015). Apabila laju kerusakan hutan mangrove tidak segera dihentikan, maka dikhawatirkan akan berakibat bagi keanekaragaman spesies moluska yang terdapat di hutan mangrove. Penelitian ini bertujuan untuk mengetahui hubungan antara kepadatan moluska dengan kepadatan mangrove terdapat pada ekosistem mangrove pesisir selatan Lombok Timur.

\section{BAHAN DAN METODE}

\section{Lokasi dan waktu penelitian}

Penelitian ini dilaksanakan di 3 lokasi, yaitu Tanjung Luar, Poton Bako, dan Teluk Jor. Setiap lokasi terdiri dari 2 stasiun yang mewakili. Waktu penelitian dilaksanakan pada bulan Januari 2021. Peta lokasi penelitian sebagai berikut:

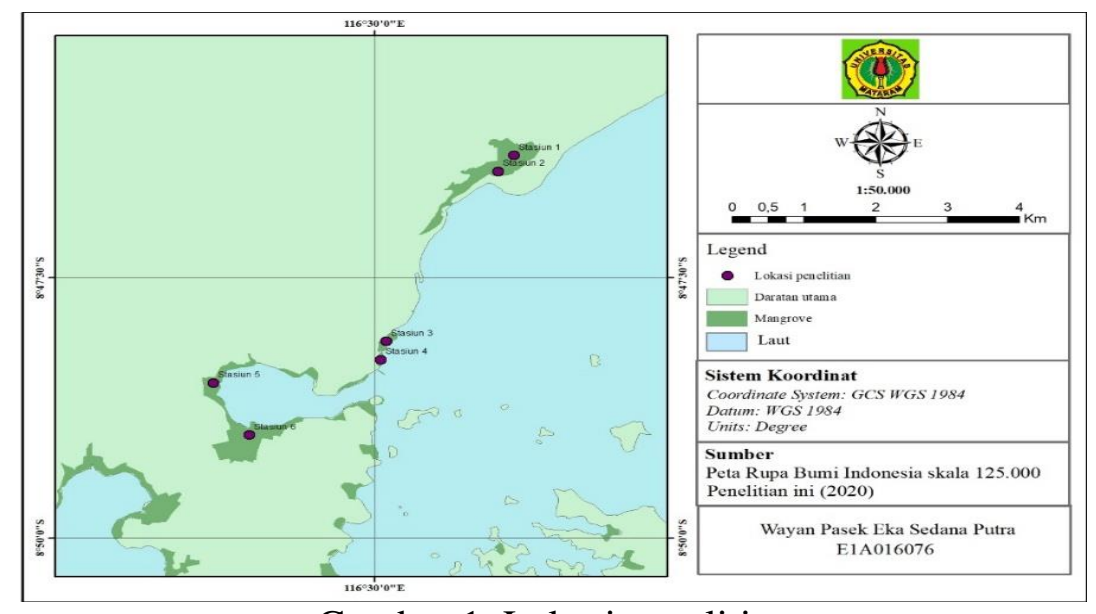

Gambar 1. Lokasi penelitian

\section{Alat dan bahan}

Alat dan bahan penelitian yang digunakan yakni GPS receiver, thermometer, refraktometer, kuadran ukuran 1x1 meter, saringan, ph meter, soil meter, roll meter ukuran 100 meter, plastik es batu, alcohol 70\%, dan wadah sampel.

\section{Pengambilan data}

Penentuan stasiun penelitian dilakukan secara purposive sampling dengan memperhatikan spesies mangrove yang dominan di Pulau Lombok, yaitu genus Rhizophora, Sonneratia, dan Avicennia (Candri et al., 2018). Setiap stasiun terdiri dari 3 plot yang dibuat tegak lurus garis pantai dengan metode transect line method (Idrus, 2014). Tiap plot berukuran 10x10 meter dengan jarak antar plot 50 meter. 
Pengambilan sampel moluska menggunakan metode quadrate sampling yang menggunakan kuadrat ukuran 1x1 meter. Peletakan kuadrat dilakukan secara purposive sampling (Candri et al., 2018) dengan memperhatikan spesies mangrove yang terdapat dalam plot 10x10 meter. Peletakan kuadrat diulang sebanyak 3 kali dalam satu plot sehingga satu stasiun terdiri dari 9 kuadrat. Moluska yang dikoleksi adalah moluska epifauna, arboreal (menempel), dan infauna yang terdapat di dalam kuadrat 1x1 meter. Pengkoleksian moluska dilakukan dengan cara hand counter atau pemungutan langsung dengan tangan. Moluska yang telah dikoleksi kemudian diidentifikasi dan dihitung jumlah individunya. Identifikasi spesimen mengacu pada Abbot \& Dance (2000).

\section{Analisis data}

Kepadatan dihitung berdasarkan rumus:

$\mathrm{K}=\mathrm{ni} / \mathrm{A}$

Keterangan:

$\mathrm{K}=$ Kepadatan spesies ke-i (ind. $\mathrm{m}^{-2}$ )

$\mathrm{ni}=$ Jumlah seluruh individu (ind)

$\mathrm{A}=$ Luas area sampling $\left(\mathrm{m}^{2}\right)$

Indeks keanekaragaman dihitung dengan menggunakan rumus Shannon-Wiener (Krebs, 1994):

$$
\mathrm{H}^{\prime}=-\sum_{i=1}^{s} P i \ln P i
$$

Keterangan:

$\mathrm{H}^{\prime}=$ Indeks keanekaragaman

$\mathrm{Pi}=\mathrm{ni} / \mathrm{N}$

$\mathrm{ni}=$ jumlah individu spesies ke-I

$\mathrm{N}=$ total jumlah individu

Indeks keseragaman dihitung dengan menggunakan rumus menurut Krebs (1994):

$$
\mathrm{E}=\frac{H^{\prime}}{\log 2 S}=\frac{H^{\prime}}{H m a k s}
$$

Keterangan:

$\mathrm{E}=$ Indeks keseragaman

$\mathrm{H}^{\prime}=$ Indeks keanekaragaman

$\mathrm{S}=$ Jumlah spesies

Indeks dominansi dihitung dengan menggunakan rumus dominansi (D) Simpson (Krebs, 1994):

$$
\mathrm{D}=\sum(\mathrm{ni} / \mathrm{N})^{2}
$$

Keterangan:

$\mathrm{D}=$ Indeks dominansi

$\mathrm{ni}=$ Jumlah individu spesies ke-i

$\mathrm{N}=$ Jumlah total seluruh individu 
Pola sebaran spesies pada habitat menggunakan indeks Morisita (Brower \& Zar, 1998), yaitu:

$$
\mathrm{Id}=n \frac{\left(\sum x^{2}\right)-N}{N(N-1)}
$$

Keterangan:

Id = Indeks Morisita

$\mathrm{n}=$ jumlah unit pengambilan contoh

$\mathrm{X}=$ Jumlah individu pada setiap plot

$\mathrm{N}=$ Jumlah total individu yang diperoleh

Analisis hubungan menggunakan analisis korelasi Pearson Product Moment (Arikunto, 2018) untuk mengetahui tingkat hubungan antara kepadatan mangrove dengan kepadatan moluska. Pedoman interpretasi koefisien korelasi " $\mathrm{r}$ " pearson product moment dapat dilihat pada Tabel 1.

$$
\mathrm{r}=\frac{n \sum X Y-\left(\sum x\right)\left(\sum y\right)}{\sqrt{\left[n \sum x^{2}-\left(\sum x^{2}\right)\right]\left[n \sum x^{2}-\left(\sum y\right)^{2}\right]}}
$$

Tabel 1. Interpretasi koefisien korelasi "r" Pearson Product Moment

\begin{tabular}{ll}
\hline Interval koefisien & Tingkat hubungan \\
\hline $0,80-1,00$ & Sangat kuat \\
$0,60-0,799$ & Kuat \\
$0,40-0,599$ & Sedang \\
$0,20-0,399$ & Lemah \\
$0,00-0,199$ & Sangat lemah \\
\hline
\end{tabular}

(Sugiyono, 2018)

Hipotesis asosiasi yang digunakan adalah:

$\mathrm{H}_{0}$ : Tidak ada hubungan antara kepadatan mangrove dan kepadatan moluska

$\mathrm{H}_{\mathrm{a}}$ : Terdapat hubungan antara kepadatan mangrove dan kepadatan moluska

\section{HASIL DAN PEMBAHASAN}

Kepadatan mangrove

Vegetasi mangrove di pesisir Selatan Lombok Timur teridiri dari 5 spesies, yaitu Rhizophora apiculata, Rhizophora stylosa, Rhizophora mucronata, Avicennia marina, dan Sonneratia alba. Spesies mangrove yang ditemukan di pesisir selatan Lombok Timur adalah spesies mangrove yang dominan ditemukan di Pulau Lombok, yaitu spesies mangrove dari genus Rhizophora, Avicennia, dan Sonneratia (Candri et al., 2018).

Vegetasi mangrove yang terdapat di Poton Bako memiliki kepadatan tertinggi, yaitu 584 ind./Ha. Tingginya kepadatan di kawasan ini diduga karena kepadatan dari Rhizophora stylosa yang sangat tinggi, yaitu 333-500 ind./Ha (Tabel 2). Hasil yang sama disampaikan oleh Safnowandi (2021) bahwa Rhizophora stylosa memiliki nilai kepadatan tertinggi di Poton Bako, baik pada substrat berlumpur ataupun lumpur berpasir. Rhizophora stylosa 
adalah spesies mangrove yang cenderung terdapat pada habitat dengan substrat berlumpur (Idrus, 2014; Lewerissa et al., 2018).

Tabel 2. Kepadatan mangrove

\begin{tabular}{|c|c|c|c|c|c|c|}
\hline \multirow{3}{*}{ Spesies } & \multicolumn{6}{|c|}{ Kepadatan pohon (ind./Ha) } \\
\hline & \multicolumn{2}{|c|}{$\mathrm{TL}$} & \multicolumn{2}{|c|}{ PB } & \multicolumn{2}{|c|}{ TJ } \\
\hline & S1 & S2 & S3 & $\mathrm{S} 4$ & S5 & S6 \\
\hline A. marina & 67 & 300 & 0 & 0 & 0 & 0 \\
\hline R. apiculata & 100 & 0 & 0 & 100 & 100 & 0 \\
\hline R. mucronata & 0 & 0 & 167 & 0 & 0 & 133 \\
\hline R. stylosa & 333 & 0 & 333 & 500 & 0 & 333 \\
\hline S. alba & 0 & 167 & 67 & 0 & 467 & 133 \\
\hline Total & \multicolumn{2}{|c|}{484} & \multicolumn{2}{|c|}{584} & \multicolumn{2}{|c|}{583} \\
\hline
\end{tabular}

TL (Tanjung Luar), PB (Poton Bako), TJ (Teluk Jor)

Sonneratia alba yang ditemukan di kawasan mangrove Teluk Jor memiliki kepadatan yang tertinggi dibandingkan lokasi yang lain, yaitu 133-447 ind./Ha. Hal tersebut menjadi penyebab utama tingginya kepadatan mangrove di kawasan ini, yaitu 583 ind./Ha (Tabel 2). Hasil yang sama disampaikan oleh Hadi et al (2019), bahwa spesies mangrove Sonneratia alba memiliki jumlah kehadiran tertinggi di Teluk Jor disusul oleh Rhizophora stylosa. Spesies ini dapat ditemukan juga pada daerah dengan substrat lumpur berpasir (Idrus, 2014). Sejalan dengan pernyataan Lewerissa et al (2018), bahwa Sonneratia alba hidup pada daerah dengan substrat berpasir dan biasanya akan berada pada zonasi yang dekat dengan laut bersamaan dengan Avicennia sp. (Lewerissa et al., 2018). Pendapat tersebut sesuai dengan tingginya kepadatan Avicennia marina di Tanjung Luar dengan nilai 67-300 ind./Ha. Spesies ini memiliki kepadatan tertinggi pada stasiun II yang letaknya dekat dengan laut. Vegetasi mangrove di Tanjung Luar memiliki kepadatan pohon terendah, yaitu 484 ind./Ha (Tabel 2). Rendahnya kepadatan mangrove di Tanjung Luar disebabkan mangrove dilokasi ini telah diubah fungsinya oleh masyarakat setempat (Idrus, 2018).

\section{Moluska di Ekosistem Mangrove}

Moluska yang terdapat di hutan mangrove pesisir selatan Lombok Timur terdiri dari 22 spesies yang mencakup 2 kelas dan 12 famili. Kelas gastropoda terdiri dari 17 spesies yang mencakup 9 famili sedangkan kelas bivalvia terdiri dari 5 spesies yang mencakup 4 famili. Hasil ini lebih sedikit jika dibandingkan dengan penelitian sebelumnya, yaitu ditemukannya 27 spesies dari kelas gastropoda dan 4 spesies kelas bivalvia (Idrus et al., 2019). Komposisi moluska dapat dilihat pada Tabel 3. 
Tabel 3. Moluska di Ekosistem Mangrove Pesisir Selatan Lombok Timur

\begin{tabular}{|c|c|c|c|}
\hline \multirow[b]{2}{*}{ Family/Spesies } & \multicolumn{3}{|c|}{ Lokasi } \\
\hline & $\begin{array}{c}\text { Tanjung } \\
\text { Luar }\end{array}$ & Poton Bako & Teluk jor \\
\hline \multicolumn{4}{|l|}{ I. Assimenidae } \\
\hline 1. Assimenia brevicula* & 0,00 & 9,67 & 6,83 \\
\hline \multicolumn{4}{|l|}{ II. Cerithiidae } \\
\hline 2. Cerithium atratum & 0,11 & 2,06 & 0,28 \\
\hline 3. Cerithium coralium* & 0,00 & 2,22 & 0,00 \\
\hline 4. Rhinocalvis aspera* & 0,06 & 0,00 & 0,00 \\
\hline \multicolumn{4}{|l|}{ III. Ellobidae } \\
\hline 5. Cassidula aurifelis* & 3,94 & 1,67 & 1,78 \\
\hline 6. Cassidula nucleus* & 6,78 & 1,94 & 1,06 \\
\hline \multicolumn{4}{|l|}{ IV. Littorinidae } \\
\hline 7. Littoraria scabra* & 2,39 & 0,94 & 3,00 \\
\hline \multicolumn{4}{|l|}{ V. Neritidae } \\
\hline 8. Nerita articulata* & 1,06 & 1,33 & 0,56 \\
\hline 9. Nerita chamaeleon & 2,39 & 2,61 & 2,39 \\
\hline \multicolumn{4}{|l|}{ VI. Potamididae } \\
\hline 10. Cerithidea cingulate* & 12,11 & 4,11 & 13,17 \\
\hline 11. Cerithidea obtuse* & 1,22 & 0,83 & 4,39 \\
\hline 12. Telescopium Telescopium* & 0,06 & 0,33 & 0,28 \\
\hline 13. Terebralia sulcate* & 4,94 & 6,39 & 7,39 \\
\hline \multicolumn{4}{|l|}{ VII. Strombidae } \\
\hline 14. Strombus canarium & 0,06 & 0,89 & 0,00 \\
\hline 15. Strombus erythinus & 0,00 & 0,11 & 0,00 \\
\hline 16. Strombus luhanus & 0,00 & 0,22 & 0,00 \\
\hline \multicolumn{4}{|l|}{ VIII. Trochidae } \\
\hline 17. Monodonta labio & 0,00 & 2,00 & 1,06 \\
\hline \multicolumn{4}{|l|}{ IX. Arcidae } \\
\hline 18. Anadara grandis & 0,00 & 0,17 & 0,00 \\
\hline 19. Anadara granosa* & 0,00 & 0,33 & 0,00 \\
\hline \multicolumn{4}{|l|}{ X. Corbiludae } \\
\hline 20. Polymesoda erosa* & 0,00 & 0,28 & 0,00 \\
\hline \multicolumn{4}{|l|}{ XI. Pteriidae } \\
\hline 21. Isognomon ephippium* & 4,17 & 9,17 & 4,39 \\
\hline \multicolumn{4}{|l|}{ XII. Yoldidae } \\
\hline 22. Yoldia tracheformis & 0,00 & 0,39 & 0,00 \\
\hline Kepadatan per-lokasi & 39,28 & 47,67 & 46,56 \\
\hline Kepadatan total & & $44,50 \pm 2,63$ & \\
\hline
\end{tabular}

*spesies moluska yang juga ditemukan oleh Idrus et al (2019)

Beberapa penelitian mengenai moluska yang terdapat di ekosistem mangrove telah dilakukan di Pulau Lombok. Isnaningsih (2015) menunjukan bahwa dari 26 spesies moluska yang ditemukan di kawasan mangrove, 25 diantaranya adalah gastropoda dan 1 bivalvia. Kemudian Candri et al. (2018) mendapatkan 47 spesies moluska yang terdiri dari 42 spesies dari kelas gastropoda dan 5 spesies dari kelas bivalvia. Berdasarkan beberapa penelitian tersebut, dapat diketahui bahwa kelas Gastropoda umumnya ditemukan lebih banyak dibandingkan kelas Bivalvia. Menurut Geist \& Hawkins (2016), kelas Gastropoda memiliki 
kemampuan adaptasi yang lebih tinggi dibandingkan bivalvia. Gastropoda juga memiliki sifat yang lebih mobile atau mampu bergerak secara aktif dibandingkan dengan bivalvia (Barnes, 1987; Hartoni, 2013; Candri et al., 2018). Selain itu, Samsi et al. (2012) menambahkan bahwa spesies dari kelas bivalvia memiliki sifat menetap dan tidak dapat bergerak secara aktif sehingga kelas ini memiliki batasan toleransi yang lebih rendah daripada kelas Gastropoda di kawasan mangrove. Tingginya kehadiran Gastropoda di ekosistem mangrove juga disebabkan kaerna sebagian besar spesies dari kelas ini adalah fauna asli ekosistem mangrove. Hal tersebut didukung oleh pendapat Budiman (1997) bahwa dari 92 spesies moluska asli hutan mangrove 90 diantaranya berasal dari kelas Gastropoda.

Secara umum, kepadatan moluska di kawasan mangrove Pesisir Selatan Lombok Timur adalah 44,50 $\pm 2,63$ ind. $/ \mathrm{m}^{2}$ (Tabel 3). Spesies moluska dari famili Potamididae (Terebralia sulcate dan Cerithidea cingulate) diduga menjadi salah satu penyebab dari tingginya kepadatan moluska di kawasan mangrove Pesisir Selatan Lombok Timur (Tabel 3). Cerithidea cingulate banyak ditemukan pada saat kondisi surut (Ziaullah et al., 2018) sedangkan Terebralia sulcate termasuk spesies gastropoda dengan tingkat adaptasi yang lebih tinggi terhadap variasi kondisi lingkungan seperti salinitas dan tipe substrat (Rahmawati et al., 2015). Selain itu, Hasan et al. (2020) menjelaskan bahwa famili Potamididae selalu hadir pada setiap zona hutan mangrove (zona bagian depan, bagian tengah, ataupun bagian belakang) dengan komposisi spesies tertinggi terdapat pada zona bagian belakang hutan mangrove.

Selain famili Potamididae, kehadiran spesies gastropoda dari famili Ellobiidae (Cassidula nucleus dan Cassidula aurifelis) dan Assimenidae (Assimenia brevicula) serta spesies bivalvia dari famili Pteriidae (Isognomon ephippium) juga memberikan kontribusi yang tinggi (Tabel 5). Merujuk pada hasil penelitian Nurfitriani et al (2019), Cassidula sp. memiliki kepadatan tertinggi di kawasan mangrove Pandansari yang dapat ditemukan menempel pada akar, batang, ataupun pada substrat berlumpur. Selain itu, Cassidula sp. merupakan salah satu kelompok gastropoda yang biasanya ditemukan hidup mengelompok di kawasan mangrove (Hamidy, 2010). Spesies dari famili Assimenidae (Assimenia brevicula) memiliki kepadatan yang tinggi pada daerah penanaman mangrove yang biasanya menjadi makanan bagi kepiting bakau dan ikan pada saat air pasang (Macintosh et al., 2002). Tingginya jumlah individu Isognomon ephippium dikarenakan spesies ini termasuk kelompok fakultatif yang dapat ditemukan pada zona bagian depan dan tengah hutan mangrove sedangkan famili Potamididae, Assimenidae, dan Ellobiidae termasuk kedalam moluska kelompok asli hutan mangrove (Budiman, 1997).

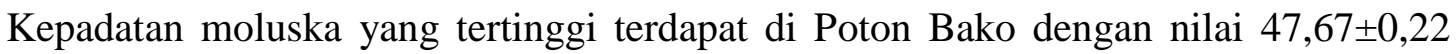
individu $/ \mathrm{m}^{2}$, Teluk Jor dengan nilai 46,56 $\pm 3,00$ individu $/ \mathrm{m}^{2}$, dan terendah adalah Tanjung Luar dengan nilai 39,28 $\pm 1,61$ individu/ $\mathrm{m}^{2}$. Poton Bako memiliki kepadatan moluska tertinggi dikarenakan pada lokasi ini ditemukan spesies moluska yang paling banyak, yaitu 21 spesies moluska sedangkan moluska yang terdapat di Teluk Jor dan Tanjung Luar sebanyak 13 spesies. Tingginya jumlah spesies di kawasan mangrove Poton Bako disebabkan lokasi ini berhadapan langsung dengan lautan sehingga memungkinkan fauna pengunjung untuk tinggal 
di dalam hutan mangrove. Hasil yang sama disampaikan oleh Hasan et al. (2020) bahwa zona bagian depan hutan mangrove yang berbatasan langsung dengan lautan memiliki komposisi spesies moluska yang lebih tinggi. Hasil penelitian menunjukan bahwa terdapat 6 spesies moluska yang termasuk kategori pengunjung yang hampir seluruhnya terdapat di Poton Bako, yaitu Strombus canarium, Strombus erythinus, Strombus luhanus, Cerithium atratum, Cerithium coralium, Yoldia tracheformis (Tabel 3).

Keanekaragaman moluska di Ekosistem Mangrove Pesisir Selatan Lombok Timur

Indeks keanekaragaman moluska di Ekosistem Mangrove Pesisir Selatan Lombok Timur dinilai berdasarkan indeks Shannon \& Wiener, dimana keanekaragaman moluska tergolong sedang dengan nilai rata - rata 2,38. Nilai indeks keanekaragaman moluska di Hutan Mangrove Pesisir Selatan Lombok Timur dapat dilihat pada Gambar 3.

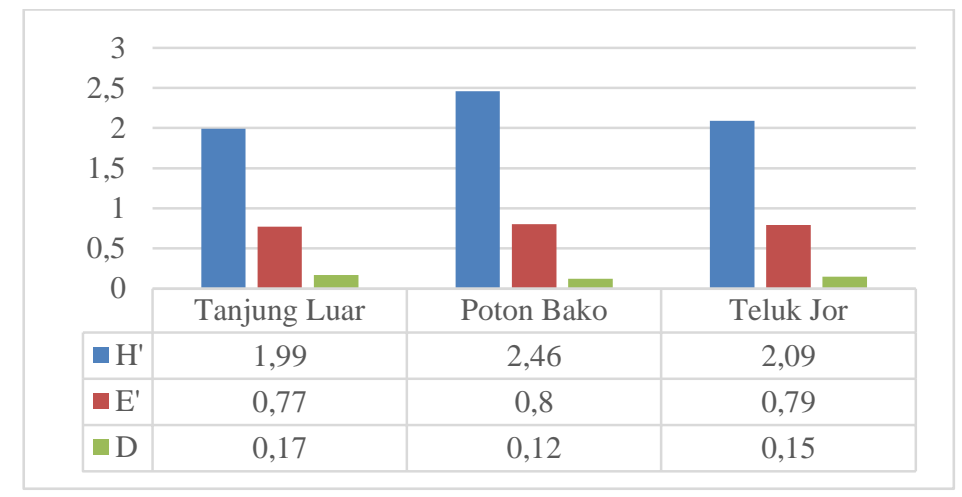

Gambar 3. Nilai indeks keaneakragaman moluska

Sesuai dengan pernyataan Rondo (2015), bahwa nilai $1<\mathrm{H}^{\prime}<3$ menunjukan keanekaragaman yang sedang. Keanekaragaman spesies suatu komunitas akan tinggi jika komunitas tersebut tersusun oleh banyak spesies dengan kelimpahan spesies yang sama atau hampir sama. Sebaliknya jika suatu komunitas tersusun dari sedikit spesies dengan adanya suatu spesies yang dominan, maka keanekaragaman spesiesnya rendah (Soegianto, 1994; Katukdoan, et al., 2018). Pendapat yang sama disampaikan oleh Pole (1974), bahwa tinggi rendahnya keanekaragaman tidak hanya bergantung pada jumlah spesies pada suatu komunitas, tetapi juga bergantung pada kelimpahan yang merata dari setiap spesies tersebut. Semakin tinggi nilai keanekaragaman suatu komunitas menunjukan komunitas tersebut semakin stabil (Odum, 1993).

Tinggi rendahnya nilai keanekaragaman dapat mempengaruhi keseragaman (E) dan dominansi (D) moluska. Semakin kecil nilai keanekaragaman (H'), maka nilai keseragaman (E) akan semakin kecil. Hal tersebut mengisyaratkan bahwa adanya dominansi (D) suatu spesies didalam komunitas (Insafitri, 2010). Jika dominansi lebih terkonsentrasi pada satu spesies, nilai indeks dominansi akan meningkat dan sebaliknya jika berapa spesies mendominasi secara bersama-sama maka nilai indeks dominansi akan rendah (Katukdoan, et al., 2018). Menurut Khouw, (2009) indeks dominansi digunakan untuk mengetahui pemusatan spesies-spesies dominan sedangkan keseragaman menunjukan kemerataan jumlah individu tiap spesies. Nilai dominansi di pesisir selatan Lombok Timur adalah 0,12 
sedangkan nilai keseragamannya 0,77 (Gambar 3). Nilai dominansi tersebut menunjukan bahwa tidak ada spesies moluska yang mendominasi di kawasan mangrove pesisir selatan Lombok Timur. Sesuai dengan pernyataan Odum (1993) bahwa nilai $0<\mathrm{D}<0,5$ menunjukan tidak adanya dominansi suatu spesies didalam komunitas. Selanjutnya, nilai keseragaman menunjukan bahwa komposisi individu antar spesies dalam komunitas merata. Apabila nilai keseragaman $(\mathrm{E})>0,6$ maka dapat dikatakan keseragaman antar populasi tinggi.

Nilai indeks keanekaragaman ( $\left.\mathrm{H}^{\prime}\right)$ pada setiap lokasi penelitian juga termasuk kategori sedang dengan nilai tertinggi terdapat di Poton Bako, yaitu 2,46 (Gamba 3). Tingginya keanekaragaman di Poton Bako dikarenakan jumlah spesies yang terdapat di lokasi tersebut paling tinggi, yaitu 21 spesies (Tabel 3). Hasil penelitian Sani et al (2020) menunjukan nilai keanekaragaman di kawasan mangrove Pemokong lebih tinggi dibandingkan kawasan mangrove Gerupuk dikarenakan jumlah spesies yang terdapat di kawasan Pemokong lebih tinggi, yaitu 34 spesies moluska. Hasan et al (2020) menjelaskan bahwa jumlah spesies yang terdapat dalam suatu komunitas menjadi salah satu faktor tinggi rendahnya nilai keanekaragaman suatu komunitas. Spesies moluska dari genus Cerithium $(C$. atratum dan $C$. Corallium) dan Strombus (S. erythinus, S. luhanus, S. canarium) memiliki peran penting dalam meningkatkan keanekaragaman di kawasan mangrove Poton Bako. Kelima spesies dari dua genus tersebut ditemukan di Poton Bako dengan kepadatan yang tinggi dibandingkan lokasi lainnya. Budiman (1997) menjelaskan bahwa kedua genus tersebut termasuk kedalam kelompok moluska pengunjung yang kehadirannya di hutan mangrove dikarenakan habitat aslinya berdekatan dengan mangrove. Pendapat yang sama disampaikan Susan et al. (2012) bahwa kedua genus tersebut lebih banyak ditemukan pada daerah intertidal dan akan semakin jarang ditemukan kearah hutan mangrove.

Kasus yang menarik tejadi di Tanjung Luar dan Teluk Jor. Jumlah spesies yang terdapat pada kedua lokasi ini sama, yaitu 13 spesies tetapi nilai keanekaragaman di Tanjung Luar $\left(H^{\prime}=1,99\right)$ tetap lebih rendah dibandingkan Teluk Jor $\left(H^{\prime}=2,09\right)$. Hal tersebut dikarenakan nilai dominansi (D) di Tanjung Luar lebih tinggi dibandingkan yang terdapat di Teluk Jor, yaitu 0,17 berbanding 0,15 . Semakin tinggi nilai dominansi menunjukan adanya suatu spesies yang mendominasi komunitas tersebut sehingga komunitas tersebut labil atau tertekan (Insafitri, 2010). Spesies yang memiliki dominasi cukup tinggi di Tanjung Luar adalah Cerithidea cingulate dengan kepadatan 12,11 ind. $/ \mathrm{m}^{2}$ pada lokasi tersebut. Populasi yang tinggi dari satu spesies dapat menyebabkan dominansi yang pada akhirnya dapat mengakibatkan terjadinya ketidakstabilan ekosistem (Isnaningsih, 2015).

\section{Pola sebaran moluska di Hutan Mangrove Pesisir Selatan Lombok Timur}

Pola sebaran moluska yang terdapat di Hutan Mangrove Pesisir Selatan Lombok Timur dihitung berdasarkan indeks Morisita (Id), dimana pola sebaran moluska memiliki nilai Id $>1$ untuk setiap lokasi. Nilai indeks Morisita dapat dilihat pada Tabel 5. 


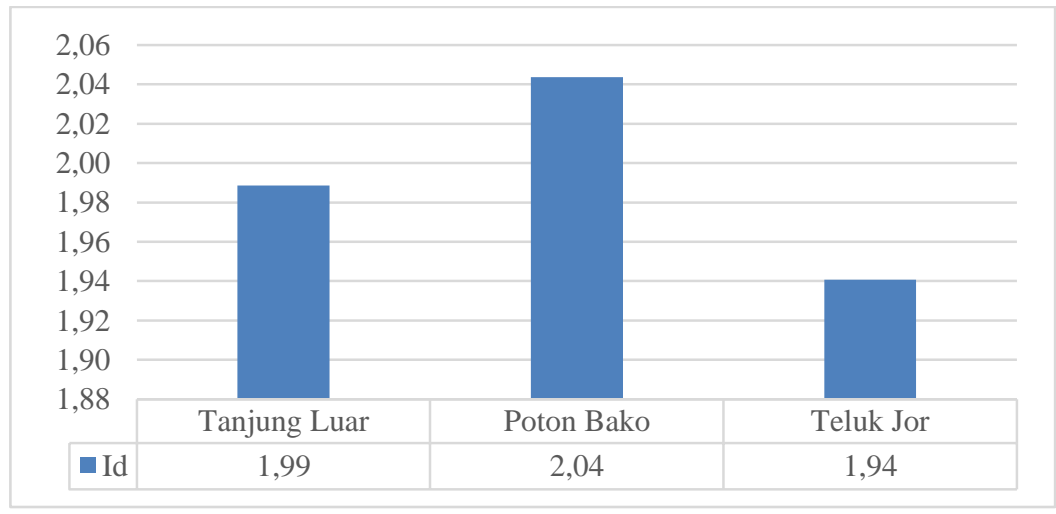

Gambar 3. Nilai Id moluska

Secara umum, pola sebaran moluska di setiap lokasi termasuk kategori mengelompok. Hal itu dibuktikan dengan nilai indeks morisita (Id) di Tanjung Luar, Poton Bako, dan Teluk Jor secara berturut-turut adalah 1,99, 2,04, dan 1,94 (Gambar 3). Nilai indeks Morisita (Id) > 1 menunjukan bahwa pola sebaran termasuk kategori mengelompok (Brower \& Zar, 1998). Pola sebaran ini termasuk yang paling umum dan terjadi secara alami di alam liar. Pendapat yang sama disampaikan oleh Sukawati et al (2018), bahwa pola sebaran mengelompok merupakan pola yang umum terjadi di alam dan sulit untuk berpindah-pindah. Hal tersebut dapat dikarenakan sumber daya makanan yang terdapat pada habitat tersebut. Sumarto \& Koneri (2016) menambahkan bahwa pola sebaran ini dapat terjadi dikarenakan sumber daya makanan yang tersebar merata pada habitatnya. Lebih lanjut lagi, Indrowati et al (2003) menambahkan bahwa pola persebaran mengelompok terjadi karena sifat suatu spesies yang suka bergerombol dan mengelompok di habitat yang banyak mengandung makanan.

Pola sebaran mengelompok juga menunjukan kesesuaian antara moluska dengan habitatnya. Merujuk pada Supratman \& Syamsudin (2018), pola sebaran mengelompok dapat disebabkan oleh kondisi habitat yang cocok sebagai tempat berlindung dan mencari makan, dan adanya interaksi individu jantan dan betina untuk melakukan proses reproduksi. Sejalan dengan pendapat tersebut, Odum (1993) menambahkan bahwa pola penyebaran mengelompok dapat terjadi secara alami dikarenakan adanya respon suatu spesies dalam menanggapi perubahan habitat dan proses reproduksi dengan pengumpulan individu pada suatu lokasi.

Berdasarkan distribusi vertikalnya, moluska yang terdapat di kawasan mangrove terbagi menjadi epifauna, infauna, dan arboreal (Mujiono, 2016). Terdapat 11 spesies gastropoda dan 1 spesies bivalvia terdistribusi diatas substrat (epifauna), 4 spesies bivalvia terdistribusi dibawah permukaan substrat (infauna), dan 6 spesies gastropoda lainnya terdistrubusi menempel di bagian pohon mangrove (arboreal) (Tabel 4). Hartoni (2013) menjelaskan bahwa sebagian besar bivalvia susah dalam bergerak dan membenamkan diri dibawah permukaan substrat. Spesies bivalvia yang distribusinya menempel pada pohon mangrove adalah Isognomon ephippium. Spesies ini adalah bivalvia arboreal yang memang sering ditemukan pada kawasan mangrove Indo-Pasific (Berry, 1975). Isognomon ephippium biasanya ditemukan pada daerah substrat lumpur dan menempel pada percabangan akar mangrove (Morton, 1983). Spesies ini bahkan dapat ditemukan membentuk agregasi yang 
terdiri dari 20 individu dalam satu titik percabangan akar pohon (Lozouet \& Plaziat, 2008). Selain Isognomon ephippium, spesies gastropoda Littorina scabra dan L. melanostoma biasanya ditemukan menempel pada tubuh pohon mangrove dan jarang di permukaan substrat. Moluska pindah ke daerah yang lebih tinggi pada saat air pasang dan kembali turun saat air sedang surut. Tetapi, saat air pasang gagal membasahi pohon mangrove, mereka kembali ke permukaan substrat (Murty \& Rao, 1977).

Tabel 4. Distribusi vertikal moluska

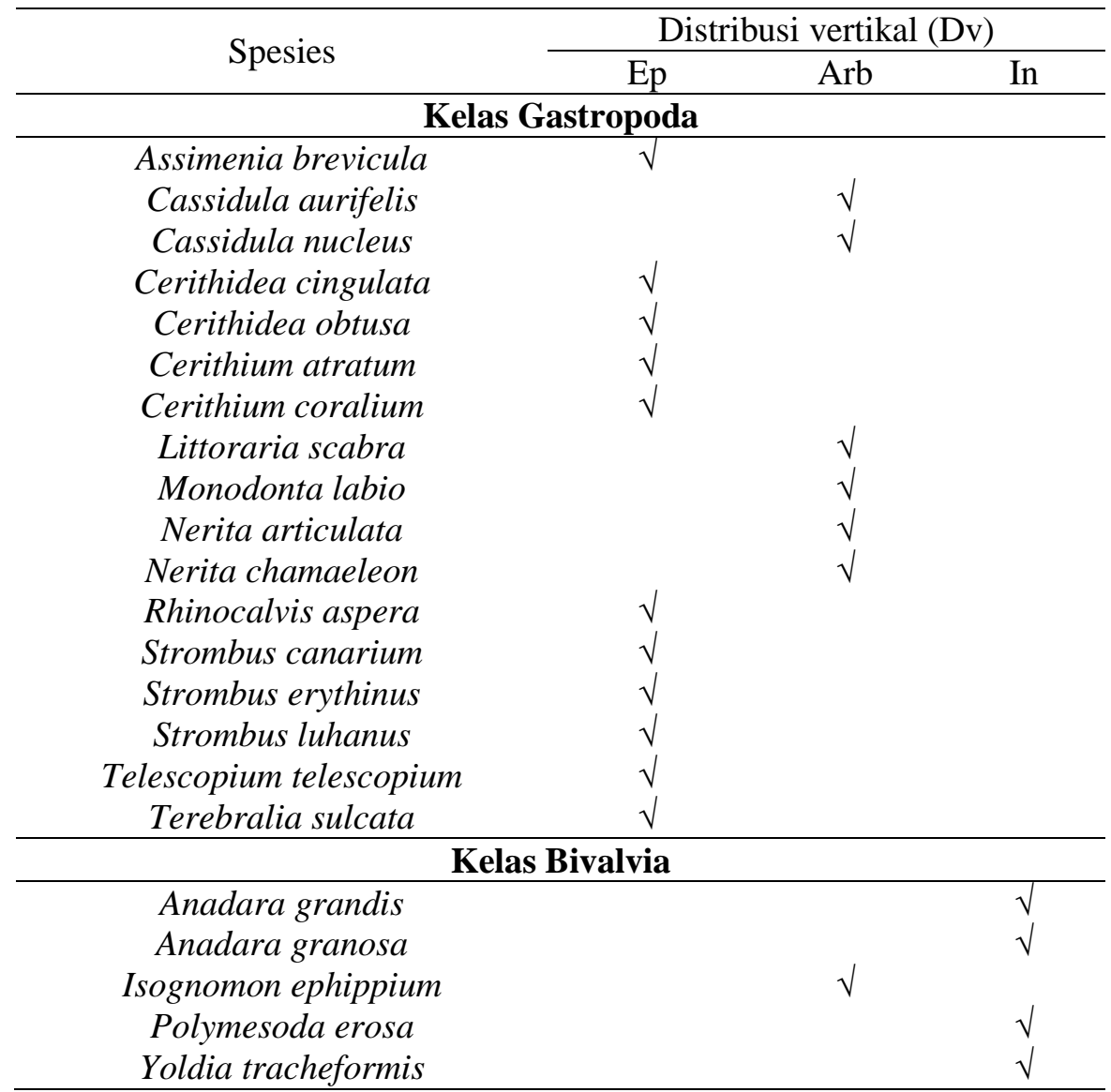

\section{Asosiasi moluska dengan mangrove}

Asosiasi spesies antara moluska dengan mangrove termasuk kedalam asosiasi inter spesies (Khouw, 2009). Pengukuran asosiasi inter spesies dilakukan dengan memperhatikan seberapa sering dua spesies ditemukan pada lokasi yang sama. Asosiasi antara moluska dengan mangrove dapat dilihat pada Tabel 5.

Asosiasi antara moluska dengan mangrove termasuk dalam asosiasi inter-spesies dan perhitungannya berfokus pada seberapa sering kedua spesies hadir dalam lokasi yang sama (Rondo, 2015). Asosiasi positif merupakan kecenderungan kedua spesies lebih sering dijumpai di lokasi yang sama sedangkan asosiasi negatif cenderung jarang dijumpai bersama (Khouw, 2009). Asosiasi antar dua spesies umumnya terjadi karena 3 hal, yaitu (1) Kedua spesies memilih atau menghindari habitat yang sama atau faktor habitat yang sama, (2) 
Kedua spesies mempunyai kebutuhan lingkungan nir-biotik dan biotik yang umumnya sama dan (3) Satu atau kedua spesies mempunyai afinitas terhadap lainnya, apakah atraksi mutualisme atau repulse (Ludwig \& Reynolds, 1988).

Tabel 5. Moluska yang berasosiasi dengan mangrove

\begin{tabular}{cccc}
\hline Spesies moluska & \multicolumn{3}{c}{ Spesies mangrove } \\
\cline { 2 - 4 } Assimenia brevicula & Rs & Am & $\mathrm{Sa}$ \\
Cassidula aurifelis & + & - & \\
Cassidula nucleus & + & & \\
Cerithidea cingulata & + & + & - \\
Isognomon ephippium & + & + & \\
Monodonta labio & + & - & \\
Telescopium telescopium & + & & \\
Terebralia sulcata & + & & \\
\hline
\end{tabular}

Keterangan: Rs (Rhizophora stylosa), Am (Avicennia marina), Sa (Sonneratia alba)

Hasil analisis data menunjukan bahwa terdapat 8 spesies moluska yang berasosiasi dengan 3 spesies mangrove sedangkan 14 spesies moluska lainnya tidak berasosiasi dengan mangrove (Tabel 5). Spesies moluska tersebut adalah Assimenia brevicula, Cassidula aurisfelis, Cassidula nucleus, Cerithidea cingulata, Isognomon ephippium, Monodonta labio, Telescopium telescopium, dan Terebralia sulcata sedangkan spesies mangrove tersebut adalah Rhizophora stylosa, Avicennia marina, dan Sonneratia alba. Hal ini sesuai dengan pernyataan Talib (2008) bahwa keeratan hubungan (asosiasi) antara spesies mangrove dengan spesies makrozoobenthos (moluska) tertentu ditentukan dengan banyaknya jumlah individu makrozoobenthos yang ditemukan pada lokasi spesies mangrove. Asosiasi yang terjadi antara spesies moluska dan spesies mangrove tersebut bersifat positif dan negatif. Asosiasi positif menunjukan kedua spesies secara tidak langsung berhubungan baik atau terjadi ketergantungan antara satu dengan yang lainnya. Asosiasi negatif menunjukan kedua spesies kecenderungan untuk meniadakan atau mempunyai pengaruh atau reaksi yang berbeda dalam lingkungannya (Rudy, 1998).

Mangrove spesies Rhizophora stylosa berasosiasi positif dengan 8 spesies moluska. Asosiasi yang positif tersebut diduga karena ekologi dari mangrove spesies Rhizophora stylosa mendukung kehidupan dari setiap spesies moluska tersebut. Printrakroon et al. (2008) menjelaskan bahwa distribusi vertikal dari Isognomon ephipphium, Monodonta labio, Cassidula nucleus dan Cassidula aurisfelis termasuk kelompok arboreal, yaitu moluska yang menempel pada bagian tubuh mangrove khususnya bagian akar dan batang. Rhizophora stylosa memiliki spesies akar tunjang yang berbentuk melengkung dengan banyak percabangan yang muncul dari batang pokok. Umumnya akar tipe ini tumbuh sekitar 1-1,5 meter diatas substrat (Idrus, 2014). Hasil penelitian Ziaullah et al (2018) melaporkan bahwa pola persebaran vertical dari moluska sangat dipengaruhi oleh pasang surut air laut. Pada saat air laut pasang moluska (gastropoda) akan memanjat pohon mangrove untuk menghindari 
genangan air dan akan kembali turun untuk pada saat air laut surut. Selain itu, Zvonareva et al (2019) menambahkan bahwa kehadiran Isognomon ephipphium di kawasan mangrove cenderung membuat agregasi pada percabangan akar Rhizophora sp. Jumlah agregasi tersebut bahkan dapat mencapai 20 individu dalam satu titik (Lozouet \& Plaziat, 2008).

Selanjutnya, mangrove spesies Rhizophora stylosa berasosiasi positif dengan moluska Assimenia brevicula, Telescopium telescopium, Cerithidea cingulata, dan Terebralia sulcata. Sesuai dengan pernyataan Idrus (2014) dan Rizal (2019) bahwa Rhizophora stylosa umumnya ditemukan hidup pada habitat dengan substrat yang berlumpur. Karakteristik substrat yang berlumpur sesuai dengan habitat yang dibutuhkan oleh keempat spesies moluska tersebut. Assimenia brevicula dapat ditemukan diatas substrat berlumpur padat dengan teduhan mangrove ataupun dibawah substrat pada daerah eustarine (Islamy \& Hasan, 2020). Genus Cerithidea dapat ditemukan melimpah pada daerah intertidal pantai, sering ditemukan berasosiasi dengan magrove yang substratnya berlumpur baik pada kawasan mangrove rehabilitasi ataupun alami (Shukla, 2014; Solanki et al, 2017; Islamy \& Hasan, 2020). Telescopium telescopium hidup pada habitat yang substrat dasarnya berlumpur dan terpengaruh oleh pasang surut air laut (Radjasa et al, 2012; Idrus, 2014). Pendapat serupa disampaikan oleh Ziaullah et al (2018) bahwa Telescopium telescopium ditemukan melimpah pada saat air laut sedang pasang.

Asosiasi negatif menunjukan kedua spesies cenderung tidak ditemukan secara bersama-sama dalam suatu habitat (Rudy, 1998). Avicennia marina hidup pada substrat berpasir dengan spesies akar nafas (Idrus, 2014; Rizal, 2019). Karakteristrik substrat tersebut kurang mendukung kehidupan dari Assimenia brevicula yang umumnya hidup pada substrat lumpur yang padat. Isognomon ephipphium berasosiasi negatif dengan Avicennia marina dan Sonneratia alba diduga karena spesies moluska ini tidak dapat menempel pada akar nafas dari Avicennia marina. Akar nafas umumnya berbentuk tombak yang tumbuh secara vertikal dan tinggi tiap akar adalah $30 \mathrm{~cm}$ (Idrus, 2014). Hal tersebut menyebabkan Isognomon ephipphium tidak dapat menempel pada percabangan akar dari spesies mangrove Avicennia marina dan Sonneratia alba.

\section{Hubungan kepadatan moluska dengan kepadatan mangrove}

Penentuan hubungan kepadatan moluska dengan kepadatan mangrove digunakan analisis korelasi pearson product moment (r). Hasil analisis korelasi antara kepadatan mangrove dan kepadatan moluska dengan menggunakan korelasi pearson dapat dilihat pada Tabel 6.

Tabel 6. Hasil analisis korelasi pearson product moment (r)

\begin{tabular}{l|l}
\hline Variabel independen $(\mathrm{x})$ & $:$ Kepadatan mangrove \\
\hline Variabel dependen $(\mathrm{y})$ & $:$ Kepadatan moluska \\
\hline Nilai $\mathrm{r}$ hitung & $: 0,95$ \\
\hline Nilai $\mathrm{r}$ tabel $_{(0,05 ; 6)}$ & $: 0,811$ \\
\hline Nilai $\mathrm{f}$ hitung $^{\text {Nilai } \mathrm{f} \text { tabel }}(0,05 ; 1 ; 5)$ & $: 41,01$ \\
\hline P value & $: 7,70$ \\
\hline
\end{tabular}


Hasil analisis korelasi pearson product moment (r) menunjukan nilai koefisien korelasi ( $\mathrm{r}$ hitung) sebesar 0,95. Nilai tersebut menunjukan kekuatan hubungan yang termasuk kategori sangat kuat (Sugiyono, 2014). Selain itu, nilai tersebut memiliki arti adanya korelasi yang positif antara variabel independen (kepadatan mangrove) dengan variabel dependen (kepadatan moluska) sebesar 0,95. Hal ini berarti semakin tinggi variabel independen akan menyebabkan kenaikan pada variabel dependen.

Selanjutnya, dilakukan penentuan signifikan (dapat digeneralisasikan) atau tidak hasil tersebut. Penentuan tersebut menggunakan perbandingan antara nilai $r$ hitung dengan $r$ tabel pada taraf kepercayaan $(\alpha=0,05)$. Berdasarkan hasil pada tabel 6 dapat diketahui bahwa $r$ hitung > $\mathrm{r}$ tabel, sehingga $\mathrm{H}_{0}$ ditolak dan $\mathrm{H}_{\mathrm{a}}$ diterima. Penentuan signifikan atau tidak hasil tersebut juga dapat dilakukan dengan membandingkan nilai $\mathrm{f}$ hitung dan nilai $\mathrm{f}$ tabel. Berdasarkan hasil pada tabel 6, dapat diketahui bahwa f hitung > f tabel, sehingga $\mathrm{H}_{0}$ ditolak dan $\mathrm{H}_{\mathrm{a}}$ diterima. Oleh karena itu, kedua hasil tersebut menunjukan adanya hubungan yang signifikan antara variabel independen (kepadatan mangrove) dengan variabel dependen (kepadatan moluska).

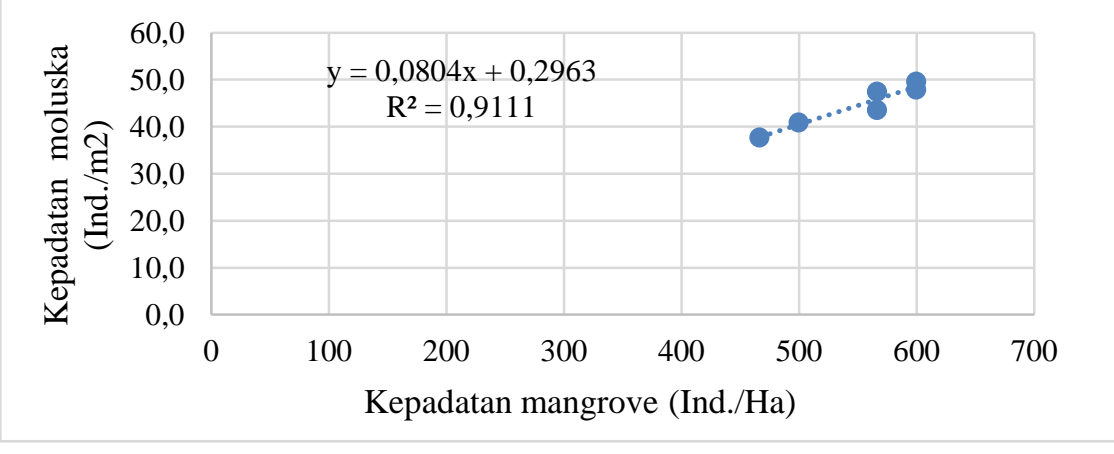

Gambar 4. Model regresi linier

Analisis regeresi bertujuan untuk memprediksi seberapa jauh perubahan nilai variabel dependen (kepadatan moluska) apabila variabel independen (kepadatan mangrove) divariasikan (Sugiyono, 2014). Nilai koefisien determinasi $\left(\mathrm{r}^{2}\right)$ menunjukan bahwa $91 \%$ variabel independen (kepadatan mangrove) menjadi faktor variasi nilai variabel dependen (kepadatan moluska) sedangkan 9\% lainnya adalah faktor lain (Gambar 4). Hasil regresi antara variabel independen (kepadatan mangrove) dengan variabel dependen (kepadatan moluska) menunjukan sifat yang positif dengan persamaan $y=0,0804 x+0,2963$. Regresi positif memiliki arti bahwa setiap kenaikan variabel independen (kepadatan mangrove) akan meningkatkan variabel dependen (kepadatan moluska) sebesar 0,0804 (Gambar 4). Hasil yang sama disampiakan oleh Nurfitriani et al (2019) bahwa kepadatan mangrove dan kepadatan moluska memiliki hasil regresi yang positif.

Adanya pengaruh yang signifikan kepadatan mangrove terhadap kepadatan moluska menunjukan bahwa vegetasi mangrove memiliki peran yang penting bagi moluska. Hasil penelitian Nurfitriani et al (2019) menjelaskan bahwa tingginya kepadatan moluska pada lokasi yang memiliki kepadatan mangrove tinggi dikarenakan lokasi tersebut memiliki produktifitas serasah yang lebih banyak. Akumulasi dari serasah (guguran dan dan ranting) 
mangrove yang tinggi akan meningkatkan kandungan bahan organik pada substrat mangrove (Nybakken, 1992; Rahmawati, et al., 2015). Selain itu, kepadatan pohon yang tinggi juga termasuk habitat yang ideal bagi biota akuatik karena memberikan perlindungan dari gangguan oleh parameter fisik dan biologis seperti predasi, kompetisi, intensitas cahaya, dan hidrodinamika (Rahmawati, et al., 2015). Pendapat yang sama disampaikan oleh Katukdoan et al (2018), bahwa vegetasi mangrove menyediakan sumber makanan, tempat berlindung dari musuh, dan air pasang tinggi sehingga pada daerah tertentu moluska akan berasosiasi pada mangrove dengan sangat baik.

Selain menyediakan sumber makanan, vegetasi mangrove juga memberikan tempat berlindung bagi moluska. Arief (2003) menjelaskan bahwa makrozoobenthos (terutama moluska) hidup menempel, melata (sesile), ataupun membenamkan di substrat perairan ekosistem mangrove. Hasil penelitian menunjukan bahwa tedapat 11 spesies moluska yang hidup diatas substrat (epifauna), 7 spesies moluska hidup dengan menempel (arboreal) di organ tubuh pohon mangrove dan 4 lainnya membenamkan diri dibawah permukaan substrat (Tabel 9). Sebagian besar gastropoda akan berpindah dari permukaan substrat dan menempel pada organ tubuh pohon mangrove. Pendapat tersebut didukung oleh pernyataan Murty \& Rao (1977), bahwa moluska (terutama gastropoda) akan bepindah ke daerah yang lebih tinggi pada saat air pasang dan kembali turun saat air sedang surut. Tetapi, gastropoda spesies Telescopium telescopium cenderung ditemukan melimpah pada saat air laut sedang pasang (Ziaullah et al., 2018). Hal tersebut diduga dikarenakan ukuran cangkang dari spesies ini cenderung besar sehingga memudahkan spesies ini berpindah pada saat air pasang. Isognomon ephipphium ditemukan melimpah pada spesies mangrove yang memiliki perakaran tunjang, yaitu genus Rhizophora. Morton (1983) menjelaskan bahwa Isognomon ephipphium ditemukan menempel pada percabangan akar pohon mangrove dengan perakaran tunjang. Spesies ini dapat ditemukan membentuk agregasi yang terdiri dari 20 individu dalam satu titik percabangan akar pohon (Lozouet \& Plaziat, 2008).

\section{KESIMPULAN}

Berdasarkan penelitian yang dilakukan dapat disimpulkan nilai indeks keanekaragam moluska di perairan hutan mangrove pesisir selatan Lombok Timur tergolong sedang dengan nilai 2,02-2,44. Pola sebaran moluska termasuk kategori mengelompok (Id > 1). Selanjutnya, 14 spesies moluska yang berasosiasi dengan 3 spesies mangrove sedangkan 10 spesies moluska lainnya tidak berasosiasi. Hasil analisis korelasi pearson menunjukan nilai koefisien korelasi (R) 0,99 dan koefisien determinasi $\left(\mathrm{R}^{2}\right)$ 0,91 yang menggambarkan hubungan sangat kuat antara kepadatan moluska (ind. $/ \mathrm{m}^{2}$ ) dengan kepadatan mangrove (ind./Ha). Kepadatan mangrove memberikan pengaruh signifikan terhadap kepadatan moluska yang dibuktikan dengan $t_{\text {hitung }}>t_{\text {tabel }}$ pada taraf signifikansi 0,05 .

\section{Ucapan Terima Kasih}

Tim penelitian menyampaikan ucapan terima kasih kepada Dekan FKIP Universitas Mataram yang telah memberikan fasilitas laboratorium untuk pelaksaan penelitian. 


\section{DAFTAR PUSTAKA}

Abdillah, B., Karnan, K., \& Santoso, D. (2019). Struktur komunitas Mollusca (Gastropoda dan Bivalvia) pada daerah intertidal di perairan pesisir Poton Bako Lombok Timur sebagai sumber belajar biologi. Jurnal Pijar Mipa, 14(3), 208-216.

Al Idrus, A., Kesipudin, K., \& Mertha, I. G. (2018). Aplikasi Konsep Konservasi Mangrove Untuk Pengembangan Ekowisata Di Pantai Selatan Lombok Timur. Jurnal Pendidikan dan Pengabdian Masyarakat, 1(1).

Arnold, P. P., \& Birtles, R. (1989). Soft-sediment marine invertebrates of Southeast Asia and Australia: a guide to identification. Australian Institute of Marine Science (AIMS).

Arief, A. (2003). Hutan Mangrove, Fungsi, dan Manfaatnya. Yogyakarta: Kanisius.

Ayu, D. M., Nugroho, A. S., \& Rahmawati, R. C. (2015). The Diversity of Gastropod as BioIndicator of Contamination of Leachate of Jatibarang Dumping Ground in Kreo River Semarang City. Prosiding Seminar Nasional Biologi , 12 (1), 700-707.

Barnes, R. D. (1987). Invertebrata Zoology (5th ed.). London: Saunders Company.

Berry, A. J. (1975). Molluscs colonizing mangrove trees with observations on Enigmonia rosea (Anomiidae). Proc. Malacol. Soc. London., 41, 589-600.

Brower, J. E., \& Zar, J. H. (1998). Field and Laboratory Methods for General Ecology. Dubuque, USA: WMc. Brown Company Publisher.

Budiman, A. (1997). Keanekaragaman dan Kelimpahan Moluska Bakau: Efek Lubang Air. Zoo Indonesia (30), 1-9.

Cappenberg, H. A. (2006). Pengamatan Komunitas Moluska di Perairan Kepulauan Derawan Kalimantan Timur. Oseonologi dan Limnologi di Indonesia (39), 75-87.

Candri, D. A., Junaedah, B., Ahyadi, H., \& Zamroni, Y. (2018). Keanekaragaman moluska pada ekosistem mangrove di Pulau Lombok. BioWallacea Jurnal Ilmiah Ilmu Biologi, 4(2), 88-93.

Candri, D. A., Sani, L. H., Ahyadi, H., \& Farista, B. (2020). Struktur komunitas Moluska di kawasan mangrove alami dan rehabilitasi pesisir selatan Pulau Lombok. Jurnal Biologi Tropis, 20(1), 139-147.

Fratini, S., Vigiani, V., Vannini, M., \& Cannicci, S. (2004). Terebralia palustris (Gastropoda; Potamididae) in a Kenyan mangal: size structure, distribution and impact on the consumption of leaf litter. Marine Biology, 144(6), 1173-1182.

Hamidy, R. (2010). Structure and Diversity of the Crab Community in the Riau Station Marine Mangrove Forest Area, Purnama Dumai Village. Journal of Fisheries and Marine Affairs, 1(3), 24-30.

Hasan, S., Serosero, R. H., \& Abubakar, S. (2020). Distribusi Vertikal dan Komposisi Moluska pada Ekosistem Hutan Mangrove di Gugusan Pulau-Pulau Sidangoli Kabupaten Halmahera Barat Provinsi Maluku Utara. Jurnal Agribisnis Perikanan, 13(1), 29-37.

Hickman, C. P., Roberts, L. S., Keen, S. L., Larson, A., I'Anson, H., \& Eisenhour, D. J. (2008). Integrated Principles of Zoology (4th ed.). New York: McGraw-Hill.

Hyman, L. H. (1967). The Invertebrates (Vol. VI). New York: McGraw-Hill Book.

Idrus, A. A. (2014). Mangrove Gili Sulat Lombok Timur. Mataram: Arga Puji Press.

Idrus, A. A., Syukur, A., \& Zulkifli, L. (2019, December). The diversity of fauna in mangrove community: Success replanting of mangroves species in South Coastal East Lombok, Indonesia. In Journal of Physics: Conference Series (Vol. 1402, No. 3, p. 033042). IOP Publishing.

Insafitri. (2010). keanekaragaman, Keseragaman, dan Dominansi Bivalvia di Area Buangan Lumpur Lapindo Muara Sungai Porong. Jurnal Kelautan, 3(1), 54-59. 
Islamy, R. A., \& Hasan, V. (2020). Checklist of mangrove snails (Mollusca: Gastropoda) in South Coast of Pamekasan, Madura Island, East Java, Indonesia. Biodiversitas, 21(7), 3127-3134.

Isnaningsih, N. R., \& Patria, M. P. (2018). Peran Komunitas Moluska dalam Mendukung Fungsi Kawasan Mangrove di Tanjung Lesung, Pandeglang, Banten. Jurnal Biotropika , $6(2), 35-44$.

Karimah. (2017). Peran Ekosistem Hutan Mangrove Sebagai Habitat Untuk Organisme Laut. Jurnal Biologi Tropis, , 17 (2), 51-58.

Katukdoan, M. W., Monika, N. S., \& Sunarni. (2018). Asosiasi Moluska (Gastropoda dan Bivalvia) Pada Ekosistem Magrove di Muara Sungai Kumbe. Agricola Journal, 8(1), 07-23.

Khouw, A. S. (2009). Metode dan Analisa Kuantitatif dalam Bioekologi. Universitas Patimura. Ambon.

Krebs, C. J. (1994). Ecology, the Experimental Analysis of Distribution and Abundance. New York: Addison-Wesley Educational Publishers.

Lewerissa, Y. A., Sangaji, M., \& Latumahina, M. B. (2018). Pengelolaan Mangrove Berdasarkan Tipe Substrat di Perairan Negeri Ihamahu Pulau Saparua. Jurnal TRITON, 14(1), 1-9.

Lozouet, P., \& Plaziat, J. (2008). Mangrove Environments and Mollusks Abatan River, Bohol and Panglao Islands, Central Philippines. Hackenheim: ConchBooks.

Ludwig, J. A., QUARTET, L., Reynolds, J. F., \& Reynolds, J. F. (1988). Statistical ecology: a primer in methods and computing (Vol. 1). John Wiley \& Sons.

Macintosh, D. J., Ashton, E. C., \& Havanon, S. (2002). Mangrove Rehabilitation and Intertidal Biodiversity: a Study in the Ranong Mangrove Ecosystem, Thailand. Estuarine, Coastal and Shelf Science, 55, 331-345.

Morton, B. (1983). Mangoves Bivalves. In K. M. Wilbur, The Mollusca (pp. 77-183). New York: Academic Press.

Mudjiono. (2009). Telaah komunitas moluska di rataan terumbu (Reef flat) perairan Kepulauan Natuna Besar, Kabupaten Natuna. Oseanologi dan Limnologi di Indonesia , 35 (2), 147-160.

Mujiono, N. (2016). Gastropoda Mangrove dari Pulau Lombok, Nusa Tenggara Barat. OLDI (Oseanologi dan Limnologi di Indonesia), 1(3), 39-50.

Murty, A. S., \& Rao, M. B. (1977). Studies On The Ecology Of Mollusca In A South Indian Mangrove Swamp. The Journal Of Molluscan Studies, 43, 223-229.

Nurfitriani, S., Lili, W., Hamdani, H., \& Sahidin, A. (2019). Density Effect of Mangrove Vegetation on Gastropods on Pandansari Mangrove Ecotourism Forest, Kaliwlingi Village, Brebes Central Java. World Scientific News, 98-120.

Nybakken, J. (1992). Marine Biology an Ecological Approach. Jakarta: PT Gramedia Main Library.

Odum, E. P., \& Srigandono, B. (1993). Dasar-dasar ekologi. Gadjah Mada University Press.

Parker, S. (1982). Synopsis and Classifi cation of Living Organisms. New York: McGrawHill Book Company.

Pole, R. W. (1974). An Introduction to Quantitative Ecology. New York: McGraw-Hill.

Putri, A., H., T., \& K., S. (2012). Keanekaragaman Bivalvia dan peranannya sebagai Bioindikator Logam Berat (Cr) di Perairan Kenjeran, Kecamatan Bulak Kota Surabaya. Jurnal Ilmu Pendidikan , 1 (2), 87-91. 
Putri, S. A., \& Patria, M. P. (2019). Peran Siput Terebralia (Gastropoda: Potamididae) Dalam Mengurai Daun Mangrove Rhizopora Di Pulau Panjang, Serang-Banten. Jurnal Kelautan dan Perikanan Terapan (JKPT), 1(2), 87-94.

Pramudji. (2001). Ekosistem hutan mangrove danperanannya sebagai habitat berbagai fauna aquatik. Oseana 26 (4): 13-23.

Printrakoon, C., Wells, F. E., \& Chitramvong, Y. (2008). Distribution of molluscs in mangroves at six sites in the upper Gulf of Thailand. The Raffles Bulletin of Zoology, 18, 247-257.

Radjasa, O., Putri, M., \& Pringgenies, D. (2012). Phytochemical and toxicity test of coarse extract of gastropod (Telescopium telescopium) on Artemia salina larvae. J Mar Res, 1(2), 58-66.

Raharjo, P., Setiady, D., Zallesa2, S., \& Putri, E. (2015). Identifikasi Kerusakan Pesisir Akibat Konversi Hutan Bakau (Mangrove) Menjadi Lahan Tambak di Kawasan Pesisir Kabupaten Cirebon. Jurnal Geologi Kelautan , 13 (1), 9-24.

Rahmawati, R., Sarong, M. A., Muchlisin, Z. A., \& Sugianto, S. (2015). Diversity of gastropods in mangrove ecosytem of western coast of Aceh Besar District, Indonesia. AACL Bioflux, 8(3), 265-271.

Reece, J. B., Urry, L. A., Cain, M. L., Wasserman, S. A., Minorsky, P. V., \& Jackson, R. B. (2014). Campbell Biology. USA: Pearson.

Rizal, L. S. (2019). Identifikasi Jenis Mangrove Di Kawasan Konservasi Laut Daerah (KKLD) Gili Sulat - Gili Lawang Kabupaten Lombok Timur. Jurnal Pendidikan Mandala, 4(5), 354-363.

Rondo, M. (2015). Metodologi Analisis Ekologi Populasi dan Komunitas Biota Perairan. Manado: Unsrat.

Rudy, G. S. (1998). Komposisi dan Assosiasi Floristik Tiga Sub Tipe Hutan Rawa Pimping PT Inhutani I Tarakan (Doctoral dissertation, Tesis Magister Program Pascasarjana Ilmu Kehutanan Universitas Mulawarman, Samarinda. 144 h).

Safnowandi. (2021). Struktur Komunitas Mangrove di Teluk Poton Bako Sebagai Buku Panduan Untuk Pemantapan Konsep. Jurnal Ilmiah IKIP Mataram, 2(1), 365-379.

Samsi, A. N., Litaay, M., \& Soekendarsi, E. (2012). Struktur Komunitas Makrozoobentos Pada Ekosistem Mangrove Di Kelurahan Tekolabbua, Kecamatan Pangkajene, Kabupaten Pangkep, Sulawesi Selatan. Moluska Indonesia, III(1), 1-10.

Sani, L. H., Candri, D. A., Ahyadi, H., \& Farista, B. (2020). Struktur Komunitas Moluska di Kawasan Mangrove Alami dan Rehabilitasi Pesisir Selatan Pulau Lombok. Jurnal Biologi Tropis, 20(1), 139-147.

Shukla, M. (2014). A Comparative Study of Macro Faunal Community of Natural and RestoredMangrove Sites between Mahi and Dhadhar River Estuaries of Gulf of Khambhat. Disertation.

Slim, F. J., Hemminga, M. A., Ochieng, C., Jannink, N. T., De La Moriniere, E. C., \& Van der Velde, G. (1997). Leaf litter removal by the snail Terebralia palustris (Linnaeus) and sesarmid crabs in an East African mangrove forest (Gazi Bay, Kenya). Journal of Experimental Marine Biology and Ecology, 215(1), 35-48.

Soegianto, A. (1994). Ekologi Kuantitatif : Metode Analisis Populasi dan Komunitas. Surabaya: Usaha Nasional.

Solanki, D., Kanejiya, J., \& Gohil, B. (2017). Ecological status of Pirenella cingulata (Gmelin, 1791) (Gastropod: Potamididae) in mangrove habitat of Ghogha Coast, Gulf of Khambhat, India. Cibtech J Zool, 6(2), 10-16. 
Sumarto, S., \& Koneri, R. (2016). Ekologi Hewan. Bandung: Patra Media Grafindo

Supratman, O., \& Syamsudin, T. S. (2018). Karakteristik Habitat Siput Gonggong Strombus turturella di Ekosistem Padang Lamun. Jurnal Kelautan Tropis, 21(2), 81-90

Talib, M. (2008). Struktur dan Pola Zonasi (Sebaran) Mangrove Serta Makrozoobenthos yang Berkoeksistensi, di Desa Tanah Merah dan Oebelo Kecil Kabupaten Kupang. Skripsi. Institut Pertanian Bogor: Bogor

Susan, V. D., Pillai, N., \& Satheeshkumar, P. (2012). A Checklist and Spatial Distribution of Molluscan Fauna in Minicoy Island, Lakshadweep, India. World Journal of Fish and Marine Sciences, 4(5), 449-453.

Wells, F. E., \& Lalli, C. M. (2003). Aspects of the ecology of the mudwhelks Terebralia palustris and T. semistriata in northwestern Australia. The Marine Flora and Fauna of Dampier, Western Australia. Western Australian Museum, Perth, 193-208.

Ziaullah, Zehra, I., \& Gondal, M. A. (2018). Studies on the vertical distribution pattern in mangrove associated molluscs along the Karachi coast, Pakistan. Indian Journal of Geo Marine Sciences, 47(01), 127-134.

Zvonareva, S. S., Mekhova, E. S., Hà, V. T., \& Kantor, Y. I. (2019). Checklist of bivalve molluscs in mangroves of Khánh Hòa Province, Vietnam. Molluscan Research, 1-17. 